\title{
Trust Drivers and Revisit Intention of Foreign Tourists in Bali
}

\author{
Wayan Ardani \\ Universitas Mahendradatta, Denpasar, Bali, Indonesia \\ ardani.shuarsedana@gmail.com
}

\begin{abstract}
Previous studies on the consequences of trust on revisit intention have been carried out both at service companies and modern retailers, but how it affects tourists rvisit intention at traditional market has not been widely carried out. This study aims to explain the factors that influence trust as well as its consequences on revisit intention of tourists at souvenir traditional market in Bali. In addition, it also explained the role of trust to mediate the effect service quality and product quality towards tourist revisit intention. A survey was conducted from foreign tourists who visited and experienced to shop souvenirs at the traditional market in Bali. The data were analyzed using the SEM-PLS approach. This study revealed that service quality had a positive and significant effect on trust and revisit intention, product quality had a positive and significant effect on trust and revisit intention, trust partially mediated the effect of service quality towards revisit intention and the effect of product quality towards revisit intention. The important factors in creating tourists trust and increasing tourist revisit intention are the ability to maintain consistency of service quality and product quality. This research is expected to prove the importance of trust to shape tourists behaviours, especially revisit intention to souvenir traditional market.
\end{abstract}

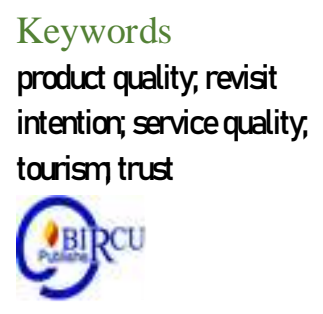

\section{Introduction}

One of the tourist favorite activities during their visit to Bali is to visit traditional souvenir markets. However, the visit of foreign tourists to traditional souvenir market decreased, despite the visit of foreign tourists to Bali increased. Traditional souvenir markets play an important role in the tourism business in Bali due to the traditional souvenir market contributes to increase employment opportunities as most of the products sold in the traditional souvenir market are produced by small and medium enterprises (SMEs). The interviews with the chief and sellers at the traditional souvenir market confirmed there was a declaination of tourist visits to the traditional souvenir markets. The declaination has been occurring because they were unable to compete with modern shops, shopping malls, supermarkets, and hypermarkets that have been popping up and selling similar products.

There were complaints from tourists about the facilities and physical evidence found in the market area, such as: lack of adequate parking facilities, market cleanliness, products were not organized well. Sellers could not communicate well because of the lack of speaking in foreign language. Some of tourists were not sure with the good reputation of the souvenir market, so it is necessary to increase tourist trust. The previous studies showed that tourist trust with destinations affected the behavior of tourists in the future. 
Previous studies showed that the ability of a company to meet customer expectations on product quality is one of the most important factors in increasing customer trust. Product quality has a significant effect on customer trust (Chinomona et al., 2013; Choi et al., 2016; Jahanshahi et al, 2011). Alongside with product quality, other factor influenced trust in retail businesses is service quality (Lien et al., 2014; Nadarajah \& Ramalu, 2018; Rasheed \& Abadi, 2014). The main concept is used to measure service quality is ServQual, that is consists of tangibles, reliability, responsiveness, assurance, and empathy (Parasuraman et al., 1988). Trust is very important in the context of the tourism business because it has an implication for future customer behavior towards tourist destinations. Studies on the consequences of trust on revisit intention have been carried out both at service companies and modern retailers. Trust influenced tourists revisit intention to a tourist destination (Choi et al., 2016; Liang et al., 2018; Artigas et al., 2017).

Based on the explanation above, the purpose of this study is to explain (1) the effect of service quality on trust and revisit intention (2) the effect of product quality on trust and revisit intention, (3) the effect of trust and revisit intention, (4) the role of trust to mediate the influence of service quality and product quality on revisit intention.

\section{Review of Literatures}

\subsection{Service Quality}

Every activity, benefits, or performance offered by one party to another party that is intangible and does not cause any ownership is called service (Kotler \& Amstrong, 2012). Dabholkar in Kusumadewi and Karyono (2019) view ServQual as more appropriate for "pure" service settings and not as applicable to the retail setting which they believe requires additional dimensions. While Sahfaq in Sukesi and Yunus (2018) service quality is a dynamic resources covering the product of goods or services, human, process, and environment that meet user expectation

Quality of service becomes a necessity factor that the firm should provide satisfaction toward customers to be able to survive and exist in the business world. Service quality is the difference between customer expectations of service to be received, and perceptions of the actual service received. ServQual has been most widely used as a reference in measuring service quality in various types of businesses such as in the fields of health, tourism, education, banking or government agencies. There are five dimensions of ServQual, that are: (1) tangibles includes physical facilities, equipment, and appearance of personnel, (2) reliability is the ability to perform the promised service dependably and accurately, (3) responsiveness is willingness aand their ability to inspire trust and confidence, and (5) empathy is caring, individualized attention the firm provides its customers (Parasuraman et al., 1988). Previous studies have shown service quality is a very important factor to build tourist trust (Nadarajah \& Ramalu, 2018; Rasheed \& Abadi, 2014) and affect consumer behavior intentions (Osman \& Sentosa, 2013). Based on empirical researches, the following hypotheses are formulated:

H1: Service quality has a positive and significant effect on trust.

$\mathrm{H} 2$ : Service quality has a positive and significant effect on revisit intention.

H3: Trust significantly mediates the effect of service quality on revisit intention. 


\subsection{Product Quality}

A characteristic of a product or service that produces the ability to satisfy and meet customer needs is called product quality (Kotler \& Armstrong, 2013). There are eight dimensions of product quality to measure product quality (Garvin, 1984), which are: (1) performance refers to a product primary operating characteristics, (2) features is the second dimension of quality that is often a secondary aspect of performance, (3) reliability reflects the probability of a product malfunctioning or failing within a specified time period, (4) conformance refers to the degree to which a product design and operating characteristics match established standards, (5) durability refers to the measure of product life, durability has both economic and technical dimensions, (6) serviceability refers to the speed, courtesy, and competence of the repair service. (7) aesthetics is product looks, feels, sounds, tastes, or smells (appearance and impression), and (8) perceived quality is the manner and feel the consumers experiment using the product. Those dimensions have been used as a reference in research on product quality in modern retail businesses. Researchers choose one or more criteria according to what is needed in the object of research (Yuen \& Chan, 2010).

The development of business organizations depends on the quality of the products they produce. The better the product produced and useful, the more consumers will enjoy it, especially to meet their daily needs (Romdonny and Rosmadi, 2019). Trusts toward a tourist destination is influenced by the ability of a tourist destination in maintaining the consistency of product quality. Previous studies have shown product quality has a positive and significant effect on customer trust (Ardani et al., 2020; Jahanshahi, Gashti, Mirdamadi, 2011) (Jahanshahi et al., 2011). There is a strong relationship between product quality and the level of customer revisit intention (Shariff et al, 2015; Suchanek et al., 2014; Jahanshahi et al., 2011). Based on empirical researches, the following hypothesis are formulated

H4: Product quality has a positive and significant effect on trust.

H5: Product quality has a positive and significant effect on revisit intention.

H6: Trust significantly mediates the effect of service quality on revisit intention.

\subsection{Customer Trust and Revisit Intention}

Trust has become a very important topic in tourism because it is an important antecedent of tourist intention to travel to tourist destinations. Trust is an important asset in developing long-term relationships with customers. An organization has to be able to recognize the factors that can build customer trust, in order to create, manage, maintain, support and enhance the level of customer relationships (Nadarajah \& Ramalu, 2018; Sayed Soliman, 2011). Customer trust includes how a company performs honesty, integrity, capability, consistency, and various other performances to shape customer trust. Trust was defined as consumers confidence in the quality and trustworthiness of the product and service provided by the company (Garbarino \& Johnson, 1999).

The theory of planned behavior (TPB) is used to explain customer behavior intention in this research. TPB is a refinement of Theory of Reasoned Action (TRA). The central factor of individual behavior is that behavior is influenced by individual intentions (behavior intention) towards certain behaviors (Ajzen, 1991a). The purpose and benefits of theory of planned behavior is to predict and understand motivational influences on behavior that is not under self control, then to identify how and where to direct strategies for behavior change and also to explain in each important aspect of human behavior such as why someone buys a bag that is very expensive or what is the reason in choosing an apartment. Behavior intention is influenced by three components that are attitude, 
subjective norm, and perceived behavior control (Sommer, 2011). Customer behavior intention is defined as the willingness of customers to buy back and recommend services to others (Canny, 2013). Revisit intention is customer's willingness to come back to a company or tourism destination in the future. A positive tourist experience about tourist destinations can produce tourist retention, which is reflected in the intention of tourists to make a return visit to a tourist destination.

Trust plays a very important role in building long-term relationships with customers because trust can create, maintain and improve relationships with customers. Numerous studies in the context of tourism have shown that trust has a positive and significant effect on tourists desire to revisit (Choi et al., 2016; Liang et al., 2018). The ability of a tourist destination to provide consistency of service quality and product quality can lead to tourist behavior intention. Trust is a very important element in fostering long-term relationships with tourists (Wang et al., 2014). The experience of tourists in a tourist destination has an effect on trust, and trust influences consumer behavior in the future, such as to recommend to others and revisit intention. The previous studies provide the reason to formulate the following hypothesis:

H7: Trust has a positive and significant effect on revisit intention.

Based on the hypothesis presented above, which are derived from the findings of previous research, this study proposes the following conceptual model (see figure 1).

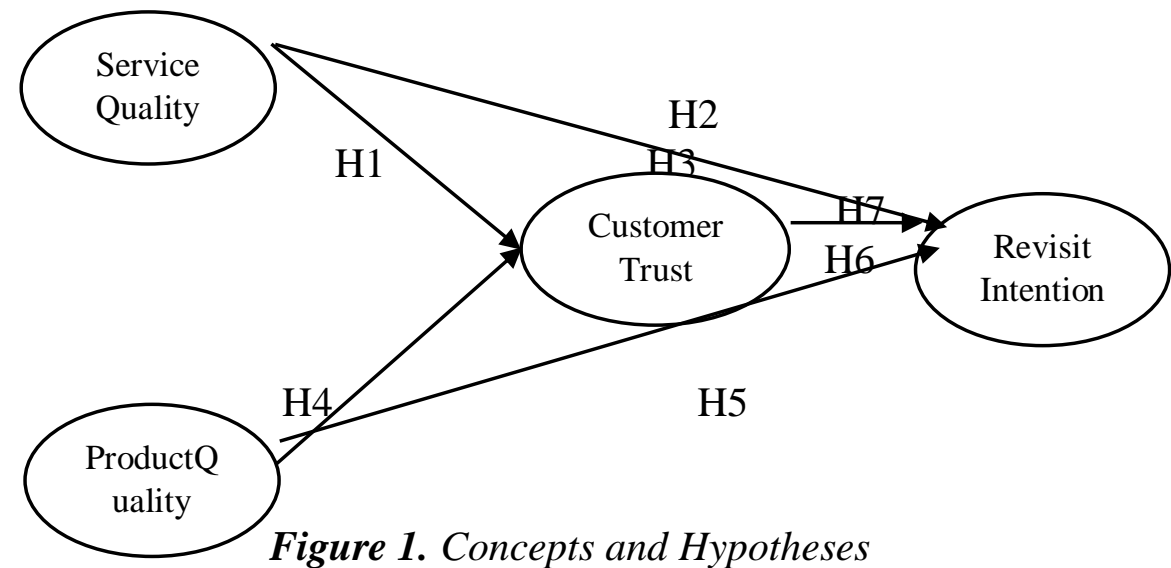

\section{Research Methods}

\subsection{Research Variables}

Variables and indicators used in this study are defined as follows:

1. Service quality consists of five dimensions, that are tangibles are reflected from indicators: parking space availability, neatness of kiosk/booth market cleanliness, and neatness of product display. Responsiveness consists of indicators: speed of service, willingness to assist tourist, the ability to respond to the tourist demands and willingness to provide information. Assurance consists of indicators: the ability to instill confidence, the ability to provide a sense of security, merchant courtesy, and the ability of sellers to answer tourist questions. Empathy is reflected with the patience of the sellers, the ability to communicate, individually attention, and understanding the specific needs of travelers. Reliability is consisted of the transaction accuracy, the speed of the transaction process, and the suitability of the service as promised. 
2. Product quality variable is reflected with four indicators: product variation, product performance, uniqueness of product design and attractiveness of product features.

3. Trust is reflected with three indicators: the good reputation of the market, the consistency of service quality and the consistency of product quality.

4. Revisit intention is reflected with four indicators, intention to visit the market when coming to Bali, consider the art market as the first choice to buy souvenirs, intention to revisit with family and intention to revisit with friends.

\subsection{Data Collection and Sample Profile}

Quantitative method is used to analyze the drivers of trust and its impact on revisit intention at souvenir traditional retail in Bali. The surveys were taken in Bali traditional art markets, i.e: Sukawati, Guwang, Ubud, Kuta, Badung, and Kumbasari, with a total of 170 persons who gave response to the survey. There were 26 indicators to be tested. The standard rule of responden number is between five to ten times of the number of indicators used, so a sample of 170 falls within an acceptable sample range. The survey data were obtained through purposive sampling, with two screenings, i.e: foreign tourists aged over 18 years old, and have been to the market so being able to provide an assessment of the quality of services and products they received and trust after their shopping experience, and a desire to return to the souvenir market, on their next visit to Bali. Table 1 presents the main data in the sample profile. All of the constructs and reflective items were measured using a five-point scale ranging from 1 strongly disagree to 5 strongly agree. This research used partial least square (PLS) modeling as implemented in Smart PLS software 3.2.8.

\section{Results and Discussion}

\subsection{Characteristics of Respondents}

Respondents in this study are foreign tourists who have visited the traditional souvenir markets in Bali. The characteristics of the respondents in this study are briefly described with gender, age, marital status, citizenship, the frequency of foreign tourists visiting Bali, and the frequency of foreign tourists visiting the souvenir market.

Table 1. Characteristics of Respondents

\begin{tabular}{|c|c|c|c|c|}
\hline $\begin{array}{l}\text { Characteristics of } \\
\text { Respondents }\end{array}$ & Description & \multicolumn{2}{|c|}{ Frequency of } & $\%$ \\
\hline \multirow{3}{*}{ Gender } & Male & 52 & & 30.60 \\
\hline & Female & 118 & & 69.40 \\
\hline & Total & 170 & & 100.00 \\
\hline \multirow{7}{*}{ Age } & $18-25$ & 16 & & 9.40 \\
\hline & $26-33$ & 23 & & 13.50 \\
\hline & $34-41$ & 19 & & 11.20 \\
\hline & $42-49$ & 18 & & 10.60 \\
\hline & $50-57$ & 35 & & 20.60 \\
\hline & $\geq 58$ & 59 & & 34.70 \\
\hline & Total & 170 & & 100.00 \\
\hline \multirow{3}{*}{ Marital Status } & Single & 63 & & 37.10 \\
\hline & Married & 107 & 107 & 62.90 \\
\hline & Total & 170 & 170 & 100.00 \\
\hline \multirow[t]{3}{*}{ Citizenship } & Asian & 28 & & 16.50 \\
\hline & Australia & 29 & & 17.10 \\
\hline & Europe & 54 & & 31.80 \\
\hline
\end{tabular}




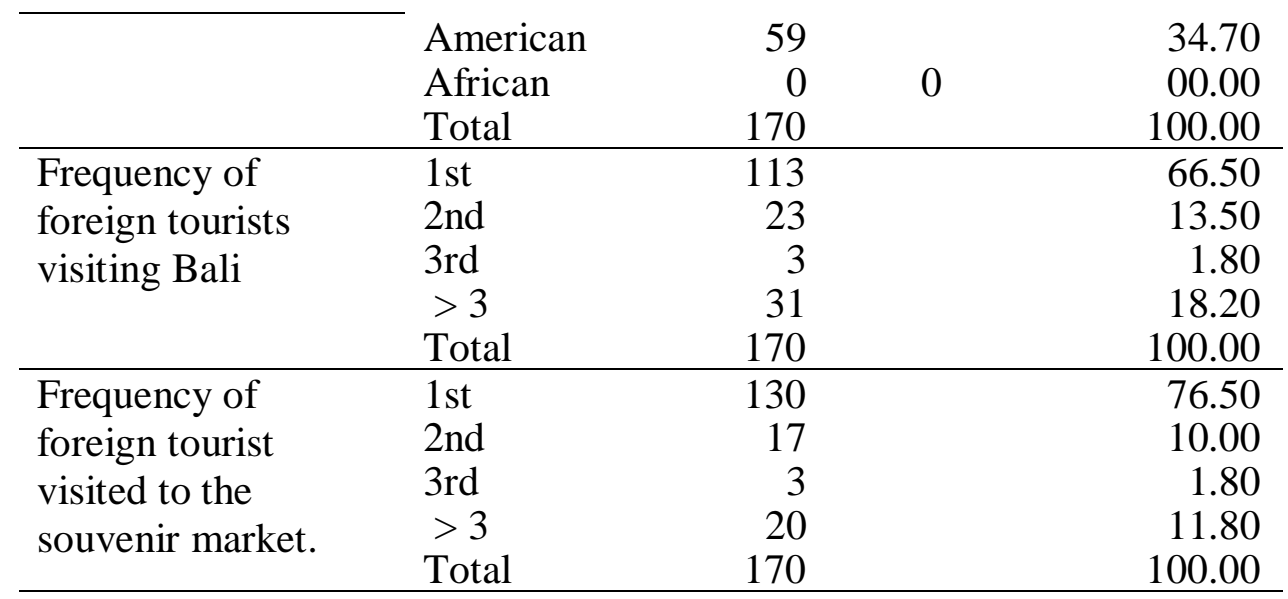

Source: Data processing results, 2019

Based on Table 1, the majority of respondents who visited the traditional souvenir market were female, which is $69.40 \%$. The dominant respondents were 58 years and above, which was $34.70 \%$. Most respondents were married, which was $62.90 \%$. In terms of citizenship, the majority of respondents came from America, which was $34.70 \%$. The majority of respondents visiting the souvenir market were respondents who came to Bali for the first time, amounted to $66.50 \%$. While based on the frequency of visits to the souvenir market, the majority of respondents made their first visit to the souvenir market, which was 76.50 $\%$.

\subsection{Validity, Reliability, Structural Model Analysis}

Before analyzing the hypotheses, the reliability of each scale was confirmed using three tests: Cronbach's alpha, composite reliability of the construct, both with a limit of 0.7 (Jöreskog, 1971), and average variance extracted is limit of 0.5 (Fornell \& Larcker, 1981). Table 2 showed all constructs are reliable as they meet the established minimum values.

Table 2. Reliability of scales

\begin{tabular}{llll}
\hline Construct & $\begin{array}{l}\text { Composite } \\
\text { Reliability }\end{array}$ & AVE & $\begin{array}{l}\text { Cronbach's } \\
\text { Alpha }\end{array}$ \\
\hline Tangibles & 0.885 & 0.659 & 0.826 \\
Responsiveness & 0.896 & 0.684 & 0.846 \\
Assurance & 0.914 & 0.725 & 0.874 \\
Empathy & 0.894 & 0.678 & 0.842 \\
Reliability & 0.873 & 0.697 & 0.782 \\
Service Quality & 0.962 & 0.572 & 0.958 \\
Product Quality & 0.916 & 0.731 & 0.877 \\
Trust & 0.908 & 0.712 & 0.865 \\
Revisit Intention & 0.904 & 0.758 & 0.841 \\
\hline
\end{tabular}

The loading factor value of each indicator is presented on Table 3. All of indicators are declared valid because they have loading factor values greater than $0.5(>0.5)$ and significant values less than $0.5(<0.05)$. 
Table 3. Validity of scales

\begin{tabular}{|c|c|c|c|c|c|}
\hline Variable & Dimension & Indicator & Coefficie & Sig. & \\
\hline Service & \multirow{4}{*}{ Tangibles } & Parking space availability & 0.887 & 0.000 & Valid \\
\hline \multirow[t]{18}{*}{ Quality } & & Neatness of kiosk/booth & 0.831 & 0.000 & Valid \\
\hline & & Market cleanliness & 0.870 & 0.000 & Valid \\
\hline & & Neatness of product display & 0.878 & 0.000 & Valid \\
\hline & \multirow{4}{*}{ Responsiveness } & Speed of service & 0.920 & 0.000 & Valid \\
\hline & & Willingness to assist tourist & 0.869 & 0.000 & Valid \\
\hline & & Respond to the tourists & 0.846 & 0.000 & Valid \\
\hline & & Willingness to provide & 0.815 & 0.000 & Valid \\
\hline & \multirow{4}{*}{ Assurance } & The ability to instill & 0.897 & 0.000 & Valid \\
\hline & & $\begin{array}{l}\text { The ability to provide a sense } \\
\text { of security }\end{array}$ & 0.791 & 0.000 & Valid \\
\hline & & Sellers courtesy & 0.888 & 0.000 & Valid \\
\hline & & $\begin{array}{l}\text { Ability of sellers to answer } \\
\text { tourist's questions. }\end{array}$ & 0.886 & 0.000 & Valid \\
\hline & \multirow{4}{*}{ Empathy } & Seller's patience to assist & 0.924 & 0.000 & Valid \\
\hline & & Ability to communicate well & 0.923 & 0.000 & Valid \\
\hline & & Individually attention & 0.884 & 0.000 & Valid \\
\hline & & $\begin{array}{l}\text { Understanding the specific } \\
\text { needs of travelers. }\end{array}$ & 0.942 & 0.000 & Valid \\
\hline & \multirow{3}{*}{ (Reliability) } & Transaction accuracy. & 0.827 & 0.000 & Valid \\
\hline & & Speed of the transaction & 0.815 & 0.000 & Valid \\
\hline & & Service suitability as & 0.904 & 0.000 & Valid \\
\hline Product & & Product variation & 0.846 & 0.000 & Valid \\
\hline \multirow[t]{4}{*}{ Quality } & & Product performance & 0.894 & 0.000 & Valid \\
\hline & & Uniqueness of product design & 0.871 & 0.000 & Valid \\
\hline & & Attractiveness of product & 0.935 & 0.000 & Valid \\
\hline & & Good reputation of the & 0.925 & 0.000 & Valid \\
\hline \multirow[t]{2}{*}{ Trust } & & The consistency of service & 0.884 & 0.000 & Valid \\
\hline & & The consistency of product & 0.930 & 0.000 & Valid \\
\hline \multirow{4}{*}{$\begin{array}{l}\text { Revisit } \\
\text { intention }\end{array}$} & & Intention to revisit next trip to & 0.865 & 0.000 & Valid \\
\hline & & $\begin{array}{l}\text { Consider the art market as the } \\
\text { first choice to buy souvenirs }\end{array}$ & 0.830 & 0.000 & Valid \\
\hline & & Intention to revisit with & 0.926 & 0.000 & Valid \\
\hline & & Intention to revisit with & 0.857 & 0.000 & Valid \\
\hline
\end{tabular}

\subsection{Structural Model Analysis}

Evaluation of the model consists of evaluating the outer model and the inner model. Outer model evaluations are distinguished by first order construct and second order construct. Evaluation on first order construct is done through convergent validity test, discriminant validity test and Forner-Locker test. Evaluation of convergent validity showed all indicators have loading factor surpass $0.5(>0.5)$, p-values less than $0.05(<0.05)$, and AVE values surpass 0.5 . It means all constructs in this study were valid and meet the evaluation criteria of the outer model convergent validity. Discriminant validity can be done by cross-loading evaluation and can also be done using the square root of average 
variant extracted ( $\sqrt{ } \mathrm{AVE})$. The results of data analysis showed that all constructs have AVE values surpassed 0.50 and the square root of average variant extracted ( $\sqrt{ } \mathrm{AVE})$ values for each variable were greater than the correlation value between the latent variable and other variables, so all indicators were valid discriminant. Reliability model is evaluated based on composite reliability (expected to be greater than 0.7 and AVE value expected to be greater than 0.5, and Cronbach's Alpha value expected to surpass than 0.7). The reliability test showed the Composite Reliability value for all constructs was greater than 0.7, the value of AVE surpassed 0.50, and Cronbach's Alpha was greater than 0.7, so all constructs were reliable. Outer model evaluation on the second order construct is a test of the path or direct effect between the first order construct with the second order construct. The relationship between first order construct and second order construct was significant and accordance with requirements test with p-value is less than 0.05.

Evaluation of structural models (inner models) is done through the approach of RSquare $\left(\mathrm{R}^{2}\right)$, Q-square predictive relevance $\left(\mathrm{Q}^{2}\right)$, and Goodness of Fit Model $(\mathrm{GoF})$. Based on $\mathrm{R}$-Square $\left(\mathrm{R}^{2}\right)$ values, all endogenous variables have $\mathrm{R}$-Square $\left(\mathrm{R}^{2}\right)$ values greater than 0.67 (> 0.67), so they are classified as strong models (Chinn, 1998). The quantity $\mathrm{Q}^{2}$ has a value with a range of $0<\mathrm{Q}^{2}<1$, the closest value to 1 means the model is better. The structural model evaluation results show $\mathrm{Q}^{2}$ of 0.98 , a value close to number 1 . The results proved the structural model was classified very good. The calculation with GoF showed a value of 0.84 which means the overall model was very fit a predictive model (Tenenhaus, 2008). It also identified the overall measurement accuracy of the model was very good. Table 4 presents the hypothesis testing result. All of the hypotheses were statistically supported.

Table 4. Hypothesis Testing Results

\begin{tabular}{|l|c|c|c|c|}
\hline \multicolumn{1}{|c|}{ Hypothesis } & Coefficient & t-statistic & $\begin{array}{c}\text { p- } \\
\text { Values }\end{array}$ & \\
\hline Quality of service -> trust & 0.575 & 7.942 & 0.000 & Supported \\
\hline $\begin{array}{l}\text { Quality of service -> revisit } \\
\text { intention }\end{array}$ & 0.174 & 1.980 & 0.048 & Supported \\
\hline Quality of product -> trust & 0.323 & 4.082 & 0.000 & Supported \\
\hline $\begin{array}{l}\text { Quality of product -> revisit } \\
\text { intention }\end{array}$ & 0,249 & 2,814 & 0,005 & Supported \\
\hline Trust -> revisit intention & 0.174 & 2.076 & 0.038 & Supported \\
\hline $\begin{array}{l}\text { Quality of service -> Trust-> } \\
\text { revisit intention }\end{array}$ & 0.100 & 2.114 & 0.035 & Supported \\
\hline $\begin{array}{l}\text { Quality of product -> trust -> } \\
\text { revisit intention }\end{array}$ & 0.124 & 2.814 & 0.005 & Supported \\
\hline
\end{tabular}

\subsection{Discussion}

Based on Table 4, it can be described significant support for the direct effect of service quality on trust and revisit intention. The ability of sellers to maintain the consistency of service quality could increase tourist trust (Nadarajah \& Ramalu, 2018) and revisit intention (Ardani et al., 2020; Osman \& Sentosa, 2013). The results of this study confirmed the Theory of Planned Behavior (TPB), which is a development of the Theory of Reasoned Action (Ajzen, 1991b). These results also provided significant support for the direct effect of product quality on trust and revisit intention The ability of sellers to maintain the consistency of good quality product increasing trust from tourists (Jahanshahi, Gashti, Mirdamadi, 2011) and revisit intention (Shariff et al., 2015). Tourist trust also 
significantly influenced revisit intention, which is in line with the previous studies (Nadarajah \& Ramalu, 2018; Wang et al., 2014).

The role of trust to mediate the effect of service quality on revisit itention is statistically supported. It was called partial mediation as service quality had a direct significant impact on trust and revisit intention, and it also had a indirect significant impact on revisit intention through trust. Trust partially mediated the effect of product quality on revisit itention. Statistically, It showed that product quality had a direct significant impact on trust and revisit intention, and it also had a indirect significant impact on revisit intention through trust.

\subsection{Research Novelty}

This study integrated service quality and product quality as drivers of trust, explained the direct influence of product quality and service quality on revisit intention, and the role of trust to mediate the effect of service quality and product quality toward revisit intention at traditional souvenir markets. Numerous studies were previously done partially, the effect of service quality on trust and revisit intention (Nadarajah \& Ramalu, 2018), the effect of service quality and product quality on revisit intention (Jahanshahi, Gashti, Mirdamadi, 2011), and the effect of quality product on trust (Chinomona et al., 2013).

\section{Conclusion}

This study theoritically confirmed the linkage of service quality, product quality with trust and revisit intention at traditional retail. It explored how service quality and product quality affected trust and its influence on revisit intention. The result of this study could be a reference for the sellers, market managers, and local government on how to increase the visit of foreign tourists to the traditional souvenirs market by increasing trust from the tourists who visited the souvenir market. The ability to provide a pleasant experience to tourists during a visit to the souvenir market has a very important role to escalate trust and tourists revisit intention. Trust is one of key factors to increase the revisit intention of foreign tourists to traditional souvenir markets. It is important to maintain the consistency of service quality and product quality to increase tourist trust and revisit intention. Trust from foreign tourists can be fostered by providing the correct information about the quality of products sold and not offering products with too high price gaps compared to actual selling prices. Market managers and sellers must work together on the hygienic of the market environment to eliminate complaints from tourists about market cleanliness

The limitations of this study that can be used as a consideration for future research as follows: Limited ability to generalize the findings of this study to domestic tourists as respondents of this study are only limited to foreign tourists. Suggested to consider comparing domestic and foreign tourists so the measurement of tourist trust is more comprehensive. Data was collected using one point in time or a cross-sectional data set, so it is suggested to consider a longitudinal time period considering there are low and high seasons in the tourism business. 


\section{References}

Ajzen, I. (1991a). Ajzen, I. (1991). The theory of planned behavior. Organizational Behavior and Human Decision Processes. The theory of planned behavior. In Organizational Behavior and Human Decision Processes.

Ajzen, I. (1991b). The theory of planned behavior. Organizational Behavior and Human Decision Processes. https://doi.org/10.1016/0749-5978(91)90020-T

Ardani, W., Rahyuda, K., Giantari, I. G. A. K., \& Sukaatmadja, I. P. G. (2020). Supply chain strategy in tourism industry for antecedents and consequences of foreign tourists shopping satisfaction on revisit intention at traditional souvenir market. International Journal of Supply Chain Management.

Canny, I. U. (2013). An Empirical Investigation of Service Quality, Tourist Satisfaction and Future Behavioral Intentions among Domestic Local Tourist at Borobudur Temple. International Journal of Trade, Economics and Finance. https://doi.org/10.7763/ijtef.2013.v4.265

Chinn, W. W. (1998). The Partial Least Squares Approach to Structural Equation Modelling. Modern Methods for Business Research.

Chinomona, R., Okoumba, L., \& Pooe, D. (2013). The impact of product quality on perceived value, trust and students' intention to purchase electronic gadgets. Mediterranean Journal of Social https://doi.org/10.5901/mjss.2013.v4n14p463

Choi, M., Law, R., \& Heo, C. Y. (2016). Shopping destinations and trust - Tourist attitudes: Scale development and validation. Tourism Management. https://doi.org/10.1016/j.tourman.2016.01.005

Fornell, C., \& Larcker, D. F. (1981). Evaluating Structural Equation Models with Unobservable Variables and Measurement Error. Journal of Marketing Research. https://doi.org/10.2307/3151312

Garbarino, E., \& Johnson, M. S. (1999). The different roles of satisfaction, trust, and commitment in customer relationships. Journal of Marketing. https://doi.org/10.2307/1251946

Garvin, D. A. (1984). What Does "Product Quality" Really Mean? Sloan Management Review.

Jahanshahi, Gashti, Mirdamadi, N. and K. (2011). Study of the Effects of Customer Service and Product Quality on Customer Satisfaction and Loyalty PhD Scholar in Business Administration. International Journal of Humanities and Social Science.

Jöreskog, K. G. (1971). Statistical analysis of sets of congeneric tests. Psychometrika. https://doi.org/10.1007/BF02291393

Kotler, P., \& Amstrong, G. (2012). Principles of Marketing Global. In USE: Pearson Education.

Kotler, P., \& Armstrong, G. (2013). Principles in Marketing Chapter 1. In Principles of Marketing.

Liang, L. J., Choi, H. C., \& Joppe, M. (2018). Exploring the relationship between satisfaction, trust and switching intention, repurchase intention in the context of Airbnb. International Journal of Hospitality Management. https://doi.org/10.1016/j.ijhm.2017.10.015

Lien, C. H., Wu, J. J., Chen, Y. H., \& Wang, C. J. (2014). Trust transfer and the effect of service quality on trust in the healthcare industry. Managing Service Quality. https://doi.org/10.1108/MSQ-11-2013-0255 
Kusumadewi, R. N., and Karyono, O. (2019). Impact of Service Quality and Service Innovations on Competitive Advantage in Retailing. Budapest International Research and Critics Institute-Journal (BIRCI-Journal). P. 366-374.

Marinao Artigas, E., Yrigoyen, C. C., Moraga, E. T., \& Villalón, C. B. (2017). Determinants of trust towards tourist destinations. Journal of Destination Marketing and Management. https://doi.org/10.1016/j.jdmm.2017.03.003

Nadarajah, G., \& Ramalu, S. S. (2018). Effects Of Service Quality, Perceived Value And Trust On Destination Loyalty And Intention To Revisit Malaysian Festivals Among International Tourists. International Journal of Recent Advances in Multidisciplinary Research.

Osman, Z., \& Sentosa, I. (2013). Mediating Effect of Customer Satisfaction on Service Quality and Customer Loyalty Relationship in Malaysian Rural Tourism. International Journal of Economics Business and Management Studies IJEBMS ISSN International Journal of Economics Business and Management Studies.

Parasuraman, A., Zeithaml, V. a, \& Berry, L. L. (1988). SERQUAL: A Multiple-Item scale for Measuring Consumer Perceptions of Service Quality. In Journal of Retailing. https://doi.org/10.1016/S0148-2963(99)00084-3

Rasheed, F. A., \& Abadi, M. F. (2014). Impact of Service Quality, Trust and Perceived Value on Customer Loyalty in Malaysia Services Industries. Procedia - Social and Behavioral Sciences. https://doi.org/10.1016/j.sbspro.2014.11.080

Romdonny, J., and Rosmadi, M.L.N. (2019). Factors Affecting Customer Loyalty in Products. Budapest International Research and Critics Institute-Journal (BIRCIJournal). P. 337-343.

Sayed Soliman, H. (2011). Customer Relationship Management and Its Relationship to the Marketing. International Journal of Business and Social Science.

Shariff, S. N. F. B. A., Omar, M. B., Sulong, S. N. B., Majid, H. A. B. M. A., Ibrahim, H. B. M., Jaafar, Z. B., \& Ideris, M. S. K. Bin. (2015). The Influence of Service Quality and Food Quality Towards Customer Fulfillment and Revisit Intention. Canadian Social Science.

Sommer, L. (2011). The Theory Of Planned Behaviour And The Impact Of Past Behaviour. International Business \& Economics Research Journal (IBER). 10(1).

Sukesi and Yunus, E. (2018). Service Quality in Public Transport Services of the Provicial Intercity Transportation (AKDP) in East Java Indonesia. Budapest International Research and Critics Institute-Journal (BIRCI-Journal). P. 161-169.

Sutrisno, S., \& Sunarsi, D. (2019). The Effect of Work Motivation and Discipline on Employee Productivity at PT. Anugerah Agung in Jakarta. Jurnal Ad'ministrare, 6(2), 187-196.

Tenenhaus, M. (2008). Component-based structural equation modelling. Total Quality Management and Business Excellence. https://doi.org/10.1080/14783360802159543

Wang, L., Law, R., Hung, K., \& Guillet, B. D. (2014). Consumer trust in tourism and hospitality: A review of the literature. Journal of Hospitality and Tourism Management. https://doi.org/10.1016/j.jhtm.2014.01.001

Yuen, E. F. T., \& Chan, S. S. L. (2010). The effect of retail service quality and product quality on customer loyalty. Journal of Database Marketing and Customer Strategy Management. https://doi.org/10.1057/dbm.2010.13 